\title{
Taiwan. The Birth of A Nation?
}

The recent presidential election witnessed the rise of Taiwanese national identity and a further failure of the Kuomintang

\section{Frank Muyard}

\section{(2) OpenEdition}

\section{Journals}

Édition électronique

URL : http://journals.openedition.org/chinaperspectives/2932

DOI : $10.4000 /$ chinaperspectives.2932

ISSN : 1996-4617

Éditeur

Centre d'étude français sur la Chine contemporaine

\section{Édition imprimée}

Date de publication : 1 mai 2004

ISSN : 2070-3449

Référence électronique

Frank Muyard, "Taiwan. The Birth of A Nation? », China Perspectives [En ligne], 53 | May- June 2004, mis en ligne le 29 décembre 2008, consulté le 28 octobre 2019. URL : http://journals.openedition.org/ chinaperspectives/2932; DOI : 10.4000/chinaperspectives.2932

Ce document a été généré automatiquement le 28 octobre 2019

(C) All rights reserved 


\section{Taiwan. The Birth of A Nation?}

The recent presidential election witnessed the rise of Taiwanese national identity and a further failure of the Kuomintang

\section{Frank Muyard}

\section{NOTE DE L'ÉDITEUR}

Translated from the French original by Peter Brown

1 On March 20th 2004, President Chen Shui-bian and his running mate Lu Hsiu-lien, who were the candidates of the Democratic Progressive Party (Minjindang, DPP) were reelected to the presidency of the Republic of China, defeating Lien Chan, President of the Chinese Nationalist Party, or Kuomintang (KMT), and his running mate, Soong Chu-yu, President of the PFP, People First Party (Qinmindang). The victory margin was extremely narrow, barely more than 29,500 votes, or $0.22 \%$ of voters, separating them. This tiny difference and the attempted assassination of the President and VicePresident the day before the ballot, the motives for which are still unknown, left the losers, until then convinced of their victory, incredulous.

2 That Lien and Soong refused to recognise the result, their decision to contest its validity in the courts, and the series of public demonstrations and protests that they have organised, have tended to mask not only the meaning of Chen's victory, but also the factors that led to Lien and Soong's defeat. The ballot recount, requested by all parties, was put back until mid-May on account of the legal path chosen by the KMT and the series of technical quibbles that it raised. Chen's victory, officially proclaimed on April 26th by Taiwan's Central Electoral Commission (CEC), should not be in doubt. All independent observers and the majority of political leaders, including those of the KMT, remarked on the quality and the transparency of the election process, leaving little room for error and even less for fraud ${ }^{1}$. It seems therefore that the re-election of Chen Shui-bian, who gave his inaugural address on 20 May, is not in question.

3 Attempting to interpret its significance, two fundamental factors appear to be behind this victory. One is a marked rise in the Taiwanese national consciousness and a 
progressive political programme of institutional and constitutional reforms. The election may have been "A vote on China" ${ }^{2}$, but it was also a "vote on Taiwan" and a "vote on the reforms", that is to say on the type of state and society desired by the population. The programmes of both camps presented the electors with markedly opposed visions. On the DPP side, a reform policy taking Taiwanese society even further from the past model and practices of the KMT regime and which offers the possibility for a new national construction based on local history and culture and the democratic expression of the individual. On the side of the KMT and its ally the PFP, the return to the proven model of political and economic management of the state and society though the apparatus of the KMT and the competence of its experts in the name of economic well-being and social stability, associated with keeping a chinese nationalist ideology and a vision of relations between government and individuals that is more technocratic than democratic. While the presidential election may well have been about "China", this vote thus also included a choice in domestic politics between, on the one hand a continuity of political experience and reforms built around the "Taiwanese community" and a national future to be constructed, and, on the other, a return to the political and national formulae brought by the KMT and the refugees from the mainland fleeing the Chinese civil war after 1945. In order to understand the virulence of the reaction of the losers in the election in the weeks following the vote, we must examine the course of an election campaign whose dynamics enabled the reelection of a President who had been widely announced as beaten a year before.

The forces at work

Officially opened 30 days before the ballot, the election campaign actually got under way in February 2003, that is more than a year before the vote, with the decision by the KMT and the PFP to propose a common list and present the two losers from the 2000 election, Lien Chan and Soong Chu-yu, as the candidates for President and VicePresident. This decision, a difficult one by virtue of the animosity between the two candidates, had several consequences. First of all, constituting an electoral alliance and a joint platform, whose fine-tuning took up most of the first half of 2003. Next, the bringing together behind the single candidature of all the conservative forces and defending a "Chinese nationalist" ideology at the expense of the "pro-local", that is "Taiwanisation" wing, of the KMT. Finally, a sense of a guaranteed victory in the presidential election, on the basis of Lien and Soong's aggregated 2000 score $^{3}$, as well as the opinion polls that gave, in the spring of 2003 , more than $60 \%$ of voters' intentions to the joint candidature. The presidential election did not therefore merely put the KMT and the DPP in opposition, but also what has been called the Alliance (Guoqin lianmeng) or the "Pan-Blue" camp (blue being the traditional colour of the KMT) and the so-called "Pan-Green" camp (green being the colour of the DPP and the proindependence movements). 


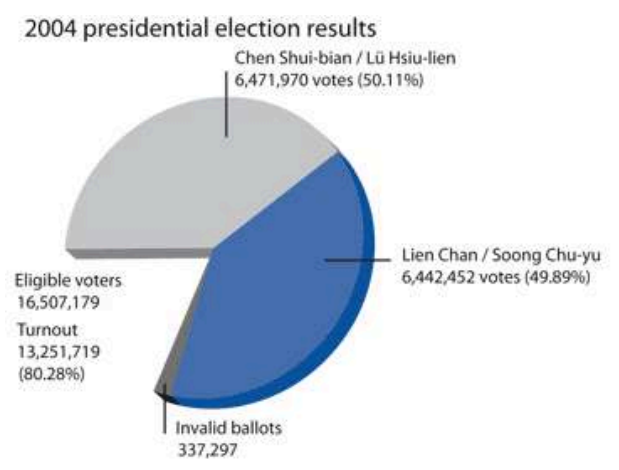

2000 presidential election results

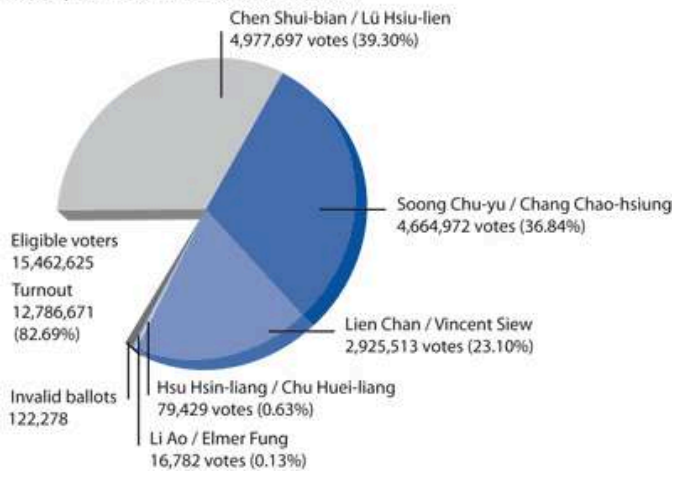

Sources: Central Election Commission (CEC), Taiwan, and Lianhe xinwen wang, Taiwan.

5 The Alliance represented more than the simple addition of the KMT and the PFP. It encompassed the circumstantial reunification around Lien and Soong of the whole galaxy of pan-Chinese ideological undercurrents that sprang from the KMT, and who were excluded from or on bad terms with the party's leadership in the Lee Teng-hui era by dint of their opposition to Lee's policy of Taiwanisation of the Republic of China. This was first of all the case for the PFP of Soong Chu-yu, who, coming out of the KMT, had run as an independent candidate for the 2000 presidential election against Lien Chan, the KMT's candidate supported by Lee Teng-hui, on a populist and explicitly panChinese and anti-Lee platform. Former governor of the province of Taiwan, who is charismatic and very popular, particularly on account of his rather client-based management of provincial funds, Soong obtained more than $36 \%$ of votes, losing by just $2.5 \%$ to Chen Shui-bian, and humiliating Lien Chan whose score barely exceeded $23 \%^{4}$. He then founded the PFP with defectors from the KMT, in large part mainlanders representing the most "Chinese nationalist" faction, careful to appoint as VicePresident of the party his 2000 running-mate, Chang Chao-hsiung, a "born-and-bred Taiwanese" from Kaohsiung.

Also included in the Alliance was the New Party (NP), the first party to have emerged from a split in the KMT in 1993 and the one most ideologically associated with the principle of reunification with China. Practically wiped off the political map in the 2001 legislative elections, most of its former leaders going to teach or work in the People's Republic ${ }^{5}$, the NP nonetheless managed to survive in the shadow of the KMT and the PFP, particularly thanks to its elected members in the Taipei Municipal Council and to Taipei's KMT Mayor Ma Ying-jeou ${ }^{6}$. Finally, we find in the blue camp the former 1996 presidential candidates, also ex-members of the KMT and anti-Lee, like Lin Yang-kang, 
Hau Po-tsun and Chen Lu-an, and their networks, which are sometimes very active, in the military and business circles with relations with China.

The green camp is composed, apart from the DPP, of the Taiwanese Solidarity Union (Taiwan tuanjie lianmeng, TSU). This political party, created at the time of the 2001 legislative elections, sprang out of a new split in the KMT, this time caused by members of the "pro-local" faction responding to the call of former President Lee Teng-hui, who was disappointed by the pro-China turn taken by the KMT under the leadership of Lien Chan after the 2000 defeat. With Lee as its spiritual father, the TSU set about defending a more radical programme than the DPP, the central planks of which were a fast-track path to independence, the international recognition of the name Taiwan and the breaking off of any political or ideological link with China. The TSU also militates for the defence of the interests of the Taiwanese lower middle classes (farmers, fishermen, workers, artisans, etc.) in the context of the speeding up of industry relocation to China and the opening up to the imports of cheap Chinese goods following Taiwan's accession to the World Trade Organisation (WTO).

8 The KMT-PFP alliance was set up to avoid the fratricidal division that allowed Chen's election in 2000, and to ground the legitimacy of his return to power, in contrast to the reduced power of a President elected with fewer than $50 \%$ of votes, as was the case for Chen. For Chen and the DPP, which never won more than $40 \%$ of the vote in a national election, the re-election was also made much more difficult. Based on the 2000 results, the blue camp clearly began 2003 in a very strong position, even if, by virtue of Lee Teng-hui's going over to the green camp, the votes mustered by Lien Chan in 2000 were perhaps not altogether vouchsafed. The objective of both camps then would be to convince the $20 \%$ of electors in the centre, who are often not very politicised, to vote for them, while consolidating their respective electoral bases (about $40 \%$ of votes each).

The general frame of the campaign was thus laid down as early as the spring of 2003. However, it was not until the end of the summer that the political debate began in earnest. Previously, a long lead-up campaign gave the opportunity to both camps to test their programmes. The campaign gradually mounted in intensity with the launch of the main election themes, then really got under way with the trip by President Chen Shui-bian to the United States at the beginning of November. We will make an assessment of both camps' programmes on the eve of this trip, before tackling the themes and the dynamics of the campaign.

The blue camp's initial strategy

In mid-August 2003, a regional by-election held in Hualien gave both camps the opportunity to test their strength and took on the appearance of a dress rehearsal for the presidential election. In spite of the atypical political situation in Hualien, the striking victory of the pan-blue candidate appeared, in the eyes of the KMT and the PFP, to successfully test their alliance and validate their campaign programme. From then on, both the programme and strategy for the presidential election were set in stone around a radical critique of the DPP government in every sphere (economy, relations with China, social and administrative policies, etc.). This critique was based on two points; the first was the economic crisis that hit Taiwan beginning in 2001 following the American and international recession, and on the rather general feeling that the Chen government had not done enough to improve the situation; the second was the stigmatisation of the incompetence of the Chen administration and its provocative stance on China that resulted in economic and political instability. The 
picture painted by the Alliance of Chen's four years in power is one of economic decline, social and human misery, and political adventurism, associated with an attitude of neglect verging on the revolutionary towards due administrative process in institutional and constitutional matters. By contrast, the competence and experience, the past proven administrative qualities and the concern for the political and economic stability of the KMT and its allies would guarantee the prosperity and security of Taiwan. The pan-blue's programme therefore invited to bring back the glory days of the KMT and of Taiwan-the years of enrichment and rapid industrialisation of the 1970 s and 1980s-through the simple return to power of the former team. Logically speaking, the Alliance's campaign began with the glorification of the former president Chiang Ching-kuo, the son of Chiang Kai-shek, who was put forward as the new father of a rich and modern Taiwan.

11 While the strength of this strategy was to take advantage of the government's mistakes and the deep concerns of the Taiwanese faced with economic crisis, as well as the widespread perception of a higher level of competence among the KMT elite in administrative and the economic matters, it had many weak points that would quickly come to light.

12 First of all, finding nothing positive in four years of DPP administration, the blue camp set everyone against it who had taken part in the state's reform programme and the policies of economic revival developed in conjunction with business circles and social groups. Moreover, in spite of a very marked drop in growth and real difficulties in the employment sector during 2001-2002 (unemployment jumping to $5.3 \%$ ), these past four years have not appeared as a descent into hell to the majority of the population. This is particularly so of the younger generation whose freedom of action and values has never been as great, and whose memory of the KMT's "good management" is fuzzy and more linked to the corruption scandals that have tarnished its reputation. This generation represented a million new voters with respect to $2000^{7}$. In addition, the KMT and the PFP have a majority in Parliament; their systematic opposition to the measures and policies of the government has seemed to many as being one of the important causes of the lack of an effective programme of economic renewal. The assessment of the Chen government's failings is thus more measured among the population than the pan-blue campaign would have us believe.

13 The next point is that the criticism of the economic achievements of a government tended to backfire as soon as there was a sign of an improvement in the economy, which is exactly what happened in summer 2003 on the twin fronts of growth and unemployment. The choice of blaming the DPP alone and of refusing to take the international recession into account, as well as the structural dependence of Taiwan on the global market thus gave all the credit for the return of growth to the government.

14 Finally, the choice of looking first and foremost to the governmental and ideological model of the Chiang Ching-kuo (CCK) years implied the complete scrapping of the legacy of the 1990s, that is, the Lee Teng-hui years. In the eyes of the majority of Taiwanese, however, it was not the CCK period, but much more the years of democratisation and "localisation", that is of the rise in the power of local Taiwanese elites who speak Taiwanese, rather than the elites who had come from the mainland after 1949. This choice of the Alliance logically stemmed from its make-up and outlook. The restructuring of the KMT around Lien Chan and an orthodox ideological line after his defeat in 2000, as well as the tactical rapprochement with Soong for the elections, 
were objectively based on a rejection of Lee Teng-hui's politics and his years in power8. The problem is that this line came into conflict with another part of the KMT's discourse which, on the one hand claimed to have fathered the democratisation of the regime and the country-forcefully imposed, nonetheless, under pressure from the population as well as from the DPP, by Lee Teng-hui on that same old guard of the party maintaining allegiance to Chiang Ching-kuo-and, on the other hand, wished to promote its Taiwanese character and its policy of localisation, that is to say, once again, the Lee heritage. While for Soong and the PFP, Lee's disavowal was not too damaging by dint of the power struggle that opposed them from the mid-1990s onwards. It was even less so for the New Party that saw in it an ideological victory. It was much more dangerous for Lien Chan, Lee Teng-hui's ex-prime minister (1994-1996) and vicepresident (1996-2000). Whereas Lee's support for independence became more radical, the impossibility of claiming credit in any credible way for the legacy of the $1990 \mathrm{~s}$ would foster the feeling that the pro-Taiwanese discourse of the KMT was a patchwork of empty slogans masking a return of the mainlanders to power and of the ideology of unification with China. Similarly, the KMT's repeated affirmation of its attachment to democracy was to counter the slogans glorifying the CCK years, but also to its inability to dissociate itself from the old guard and the party's authoritarian past symbolised by Soong and by the reappearance around the Alliance of the most orthodox conservatives in the old KMT and the NP9.

The Blues' campaign consisted in attacking the candidate chen Shui-bian and his administration by all possible means-not only politically and economically, but also morally and personally-, and in promoting the competence of the KMT-PFP in order to ensure the well-being of the population. The fundamental contradictions in their discourse would, however, jeopardise their chances as soon as the electoral debate went from a critique of the Chen government's policies to questions of identity and constitutional changes.

The green camp's initial strategy

16 At the start of the election campaign, the DPP and Chen knew that the political and economic situation was against them. The alliance between Lien and Soong forced Chen to obtain $50 \%$ of the votes, that is $10 \%$ more than in 2000 , if he was to be re-elected. In the face of this challenge, the Greens' strategy was simple: to have people forget the mistakes and inexperience of the administration by playing on the traditional strengths of the green camp (democracy, Taiwanese identity, listening to the people), promote the pursuit of the reforms begun during the first term of office, and discredit the blue camp's candidates and discourse by associating them with the dictatorial, antiTaiwanese and corrupt past of the old KMT. This led to a dual campaign: a national one proposing new ideas in line with the old attacks on the blue camp, and a multitude of local micro-campaigns designed to muster as many votes as possible. The "mission impossible" of increasing the number of green votes by $10 \%$ was to be translated into objectives quantified in terms of votes to be garnered for each circumscription, city, town, village and district throughout the country, but especially in the south, a traditional bastion of pro-independence supporters, and the Centre, where the government's generous policies of economic and cultural development had offered fertile ground for the past four years.

17 The DPP was to be supported in that by the Lee Teng-hui's Taiwan Solidarity Union (TSU), which threw the whole of its networks and resources into the battle for Chen's 
re-election. The TSU was even to play the role of catalyser of the most radical proindependence forces, offering the DPP the opportunity of putting itself back at the centre of the political stage and putting on a more moderate face likely to attract a broader electorate. Beginning in the spring of 2003, the TSU prepared a series of demonstrations to demand an official name change of the Republic of China into "Taiwan" and a revision of the Constitution. The outbreak of SARS (Severe Acute Respiratory Syndrome) forced it to put off these activities until September, but SARS was also to give grist to the independence mill. The epidemic, the circumstances of its being spread from China, the secrecy surrounding it that was maintained for the first few months by the authorities in Peking, and China's refusal to authorise official contacts between Taiwan and the World Health Organisation (WHO) were to remind the population, after a recent period of infatuation with Shanghai and the Chinese economic miracle, the risks implicated by the Chinese communist system, as well as China's contempt for the well-being of Taiwanese and Chinese alike ${ }^{10}$.

This anti-China sentiment in a scared population that was housebound for nearly two months gave the DPP the opportunity to bring back one of the main planks of the proindependence platform to the fore: the holding of referenda to enable the population to express its views directly on government policies and the great national objectives. On May 20th, Chen Shui-bian broadcast his wish to organise a referendum on Taiwan's accession to the WHO at the same time as a presidential election. For that, Parliament, which was controlled by the KMT-PFP opposition, had to pass a law. Therefore, during 2003 , the passage of the law on referenda became one of the principal hobbyhorses of the DPP.

The second theme put forward by the green camp was the setting up of a new Constitution. This idea, which had been tried out during the summer by the DPP, took on greater force after the unexpected success of the September 6th demonstration for a name change for Taiwan. Organised by the TSU and bringing together more than 200,000 people, this demonstration was the occasion for Lee Teng-hui to call for a new Constitution for 2008. On September 28th, Chen Shui-bian announced the objective of introducing a new Constitution by referendum in 2006 and its implementation in 2008.

The third plank in the Greens' campaign consisted in systematically discrediting the KMT. The DPP strived to undermine the credibility of the blue camp through constant revelations of malpractice and refusal to make amends for the political and economic injustices of the years of KMT dictatorship. Without denying the competence of the administrators in the blue camp, that it had tried for four years to entice into the government (with some modest success), the DPP wanted to emphasise that the political leaders of the blue camp remained corrupt and that they had made no distinction between public and private funds. The attacks, very often ad hominen, concentrated on the KMT and its leaders getting rich at the expense of the nation, and on the suspicious origins of the immense family fortune that Lien Chan had amassed since the 1950s, given that he had been, as his father before him, a top bureaucrat all his life $\mathrm{e}^{11}$. 
Geographical distribution of votes (\%)

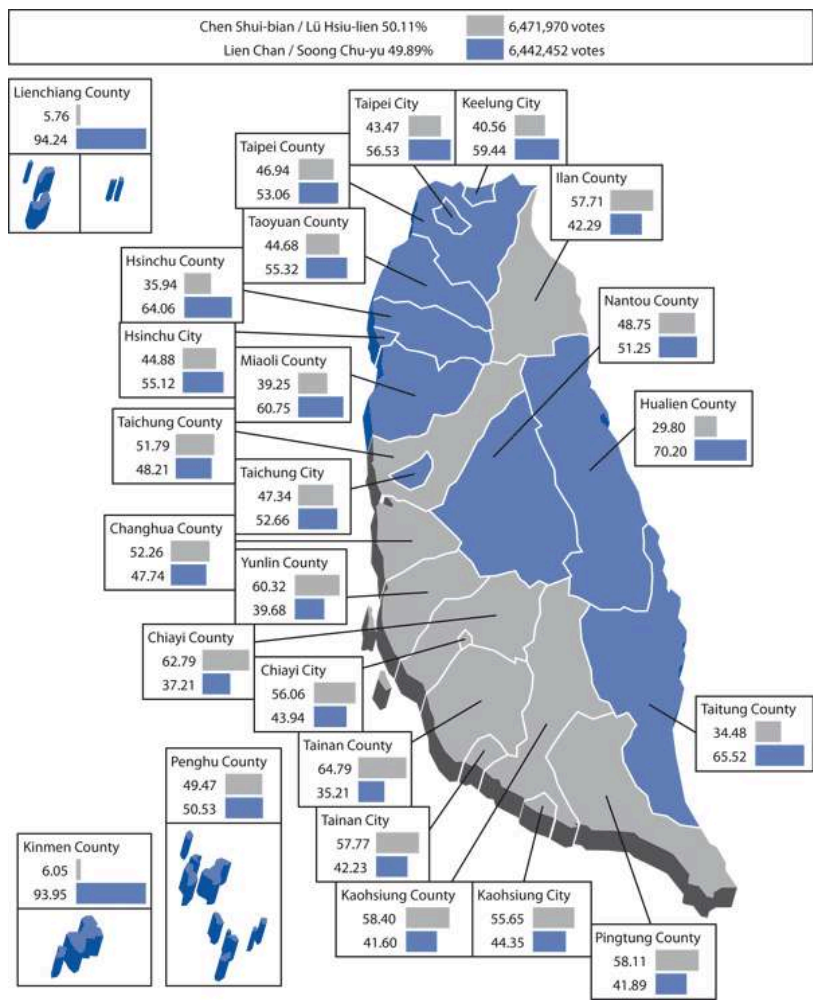

Source: Central Election Commission (CEC), Taiwan.

21 A few weeks after the defeat of its candidate in the Hualien by-election, the green camp thus also laid out the three central planks of its campaign. These were a referendum, a new Constitution and a rejection of the corrupt rule of the KMT, all themes that would enable it to get the election debate away from assessments of government performance and put it back on the questions of choice about identity and policy. From then on, the dynamics of the election campaign were to go from the blue camp to the green camp, and the agenda would be almost entirely set by the DPP. Chen Shui-bian's and Lee Teng-hui's superior mastery of the art of politics led to the situation where all the themes that the blue camp wished to avoid were precisely those that the DPP had put at the core of its election strategy and were also those that would resonate with voters. The campaign strategy of the Blues, worked out and applied in a quasi technocratic way, forgetting the idealistic dimension of any political campaign, and relying on nationalistic affinities and identifications out of step with changes in people's mentality, would very quickly run aground. The blue candidates were to spend their time glued to the DPP campaign, especially after Chen Shui-bian's trip to the United States.

Chen's trip to the United States and the pan-blue's turn-around

The trip made by President Chen Shui-bian to the United States at the beginning of November 2003 represented a major turning point in the campaign. This was a nonofficial trip-Washington's Chinese policy not allowing otherwise-and the six days spent by Chen on American soil were formally regarded as being a mere stopover by the Taiwanese President on his way to paying a visit to his diplomatic allies in Central America. However, the awarding of the 35th International Human Rights Prize to Chen by the International League of Human Rights at a ceremony in New York, in the course 
of which he was allowed to make a public address, but also the length, number and importance of his stopovers (New York, Los Angeles, Houston, Alaska), as well as the welcome given by top dignitaries in both the American executive and Congress, made this trip the most successful, the most "official" and the most widely covered by the media of any Taiwanese leader since 1979. Following on from a series of contacts and trips by ministers and officials in the military, diplomatic and economic spheres between Taiwan and the Unites States, it gave the impression of Washington's total support for Taiwan and even more for President Chen and his policies of democratic reform ${ }^{12}$.

The most obvious repercussion of the success of this trip was the spectacular turn around of the KMT-PFP alliance on the three major issues of the referenda, the revision of the Constitution and relations with China. All through the summer and the beginning of autumn, Lien Chan and the political machine of the KMT had radically rejected and ridiculed the DPP's ideas on these matters. In November, however, they took them on as their own to the point of outbidding its rival. On November 12th, for the first time Lien Chan supported the holding of a referendum and the passing of a law to this effect. On November 15th, he proposed a three-stage revision of the Constitution of the Republic of China, leading to a new Constitution as early as 2005. At the same time, Lien Chan, and even Soong Chu-yu, made a series of announcements concerning relations with China. First of all recalling their rejection of Peking's proposed model of "one country, two systems" (yi guo liang zhi), and of any relinquishing of the sovereignty of the Republic of China over Taiwan, and even over China, in any possible negotiations with Peking. They then explicitly rejected Peking's "one China principle". Lien Chan and Wang Jin-pyng, the campaign director for the Blues, even went as far as to publicly recognise the reality of the existence of a state (if not a country) on either side of the Strait, thereby directly echoing Chen Shui-bian's formula (yi bian yi guo) ${ }^{13}$.

The reason for such a change does not lie only in Chen's successful trip to the United States. Besides Washington's support for the democratic reforms, in the logic of the Bush administration's global foreign policy, the KMT became aware that the DPP's proposals had broad agreement among the population to the extent of beginning to tip the electoral scales. As proof, the first opinion polls giving Chen as the winner in the presidential election came out in November. From that moment on, the blue camp would run behind the DPP to prove its attachment to Taiwan and democracy. What should have been a campaign on the government's performance became a competition in identification with Taiwan and love of the motherland. The only problem was that for the KMT, and even more so for the PFP and the NP, the motherland is China, albeit a non-communist China.

The new explicitly pro-Taiwan discourse, copied from the programme of the DPP, clearly showed the impasse in which the blue camp's strategy, like its ideology, found itself in the middle of the campaign. The Pan-Blues probably had no choice. At the start of December, an opinion poll conducted by the Zhongguo shibao (China Times) indicated that the number of Taiwanese who considered themselves to be solely Taiwanese reached $50 \%$ for the first time, as against $38 \%$ who considered themselves to be Taiwanese and Chinese, and $9 \%$ Chinese only ${ }^{14}$. In these circumstances, to carry on with an overtly pro-Chinese policy and campaign, one centred on a return to a pre-Lee Teng-hui past, would have been tantamount to political suicide. However, having both a pro-Taiwan discourse and one that advocated rapprochement with China based on a 
pan-Chinese ideology could not but give an impression of confusion and publicise the factional fighting between the Taiwanese way and the Chinese way within the blue camp. Finally, the major consequence of the Alliance's turn-around on national and constitutional questions, of which its leaders were perhaps not immediately aware, was the final legitimisation of the DPP policy and its pro-independence line among the majority of the population.

It is possible, however, to think that the KMT's public reversal was above all an election tactic of Lien and Soong that in no way called into question the principles, still intangible ones, of the "Chinese nationalist" platform of any likely pan-blue government. A certain number of factors seem to give credence to this view. Indeed, with the exception of parliamentary Speaker, Wang Jin-pyng, a rather consensual and self-effacing character, the campaign of the blue camp did not make any significant call on its pro-local wing. Vincent Siew (Hsiao Wan-chang), the first vice-president of the KMT, was one of those most notably absent. Generally speaking, the Alliance made little of the propositions and ideas stemming from the Taiwanese faction except in case of emergency, and one may wonder whether this was not done reluctantly ${ }^{15}$.

Lian Chan on the campaign trail

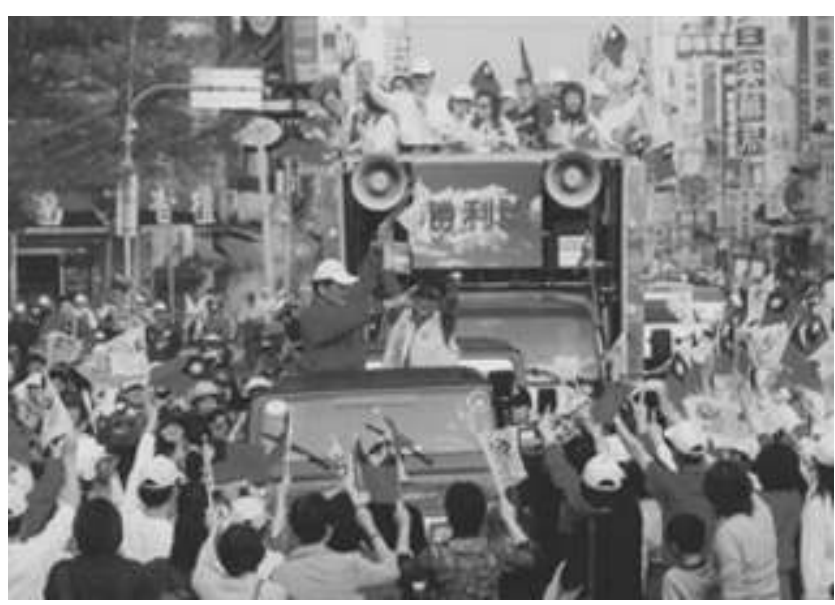

(C) GIO

The blue camp's election strategy was thus based on four leaders each having their own list and public: Lien Chan, with his image as an austere and competent traditional leader, a future President above the in-fighting and one with Taiwanese roots; the populist and provocative Soong Chu-yu drew in the older mainland generations and his personal clique; Ma Ying-jeou, golden boy and vice-president of the KMT, general secretary of the national campaign, attracting the younger generations and the middle classes in the north of the island by his seriousness, politeness, charm, and his legal background; finally, Wang Jin-pyng, vice-president of the KMT and member of parliament for Kaohsiung, a symbol of the pro-local wing, who was director of the national campaign with specific responsibility for the southern region. Three out of the four were born in mainland China (Lien in Xi'an, Soong in Hunan province and Ma in Hong Kong, the latter into a family of KMT notables who originally came from Hunan province and passed through Hong Kong on their way to Taiwan). The fact that, in common with most of the major leaders in the blue camp, they have recent mainland 
connections, could not but confirm the popular impression of a KMT looking more towards the past and China than towards Taiwan.

Nonetheless the four made considerable use of the Taiwanese language in their speeches and interviews, and increasingly as election day approached. This is less true of Ma Ying-jeou who campaigned especially in the North where the majority is made up of families with a mainland background and Hakkas, and who could not speak Taiwanese just ten years previously. Lien and Soong use Taiwanese more freely and frequently, even if one can sense a certain unease in freewheeling conversations and a tendency to resort to Mandarin to express their ideas with precision and conviction (quite the opposite of most of the DPP or TSU leaders, beginning with Chen and Lee). Although Lien Chan's family is originally from Tainan, he has never managed to convince people about the authenticity of his attachment to Taiwan, being, it is true, in competition with Chen Shui-bian, a real "son of Tainan" and of Taiwan ${ }^{16}$. This meant that Wang Jin-pyng was alone to carry the flag of Taiwanisation with conviction. He would do it with strength and perseverance to the extent of calling into question some of the implicit fundamental principles of the KMT. Going a step further than his boss, Wang would therefore insist on the political necessity of the public and official use of Taiwanese, and even of raising the independence of Taiwan as an acceptable alternative for the future ${ }^{17}$.

The tensions between Wang and the other leaders of the blue camp, particularly Soong, came out in any case on several occasions, notably in Wang's initial refusal to assume the role of national election campaign director on the grounds of having doubts about the sincerity of Lien's and Soong's dedication to the well-being of the population. However, Wang clearly made all his declarations with Lien Chan's agreement. He also actively supported contesting the election results after March 20th, at the risk of losing his reputation of impartiality in Parliament and his credibility within the electorate in the south, which confirms his loyalty to Lien and the KMT. We should probably perceive the rhetorical differences and reversals therefore mainly as an electoral tactic by the blue camp to harness the maximum number of votes possible, and especially in order not to lose the "pro-Taiwan" votes of the KMT, yet without really giving up the party's Chinese ideology. To do so, as was partially the case under Lee Teng-hui, would completely jeopardise the very foundations of the KMT as well as the support of that section of the population that still identifies with China.

Thus, on the question of relations with China, the Alliance's apparent turn-around in favour of the recognition of the existence of two states should not lead to any misapprehension. While the "pro-Taiwanese" faction in the KMT has ratified the historical and political reality of the separation from China, and taken on board the fact that the population's identification with a purely Taiwanese identity has made constant strides forward over the past two decades, the ultimate goal of the present leadership of the blue camp, and in particular of the political apparatus of the PFP and the NP, remains in the long term reunification with China and the maintenance of a Chinese nationalist ideology ${ }^{18}$. In order not to put the KMT's internal disputes on display and show too clearly the gap between its programme and the views of the majority of the population, Lien proposed that the solution to the questions of sovereignty and independence be left up to future generations and, for the meantime, avoided political subjects in discussions with China concentrating instead on economic matters. He was 
consistent in maintaining this position and the related, albeit unrealistic one, of claiming the Republic of China as the sole China.

The Referendum Law and the crisis with the United States

This electoralist speculation has confirmation in the battle to pass the Referendum Law. This battle continued for more than six months-the DPP, in favour of a nonrestrictive law on referenda, and the Blue alliance, which, despite giving its support in theory, first of all used its majority in the Chamber to reject any law concerning this subject on two grounds. It was put forward that the public are not always the best judge and that decisions should ideally come either from the people's representatives in Parliament or from qualified experts on the issues under debate. It was further suggested that it would be a provocation to China. Given the massive support of the population to the creation of the instruments of direct democracy as a complement to representative democracy, and Washington's acquiescence, in November the blue camp changed its position. During the parliamentary negotiations, the DPP accepted ruling out from any referendum the questions of the sovereignty, the name and the flag of Taiwan, in exchange for one article (the future Article 17) enabling the holding of referenda on national security initiated by the President in case of threats to the sovereignty of the country.

The law passed on November 27th was, however, very far from what had been planned. To the surprise of all, including Washington, the law that was drawn up and voted solely by the KMT and the PFP, with the exception of Article 17 that the DPP managed to get through, is extremely restrictive. Such as it is, it allows for a referendum only on the basis of a petition backed by at least $5 \%$ of registered voters (that is more than 800,000 ), and after the subject has been approved by a specially established committee the members of which would be a pro rata representation of parties in Parliament. This law would seem to make any calling of a referendum for the presidential election by Chen Shui-bian and the DPP impossible, and was therefore considered to be a major political victory for the Alliance. Seen as a setback for the introduction of steps towards direct democracy on Taiwan, the law was also welcomed as a victory by Peking. The secret surrounding its preparation by the blue camp until the eve of the vote, and the virtually synchronised mix of warnings and assurances expressed by China about a favourable outcome, raised moreover the question of the degree of implicit understanding between the leaders of the blue camp and the government in Peking.

The battle surrounding this law reinforced the impression among analysts and the general population that the KMT and the PFP do not pay much heed to the wishes of the majority of Taiwanese. It has also posed the question of the limits of the blue camp's commitment to democracy and political and constitutional reforms, highlighting the essentially electioneering character of its initial about-face on the issue of referenda.

The fury of the opposition was, however, quickly to succeed the anger of the government and the DPP at this "iron-cage law" following a political "coup" by Chen Shui-bian. Indeed, Chen relied on Article 17 and the presence of more than five hundred Chinese tactical missiles off the Taiwanese coasts to call for two referenda on relations with China and national defence to be held on the day of the presidential election. The reasons for this decision were, on the one hand, Chen's desire to maintain the constitutional precedence of the executive power over the National Assembly, whose cohabitation within a half-American, half-French style presidential system had 
been a headache for four years, and, on the other hand, the conviction that not only would the referenda be an effective means of mobilising the electorate, but also the presidential election might be the last chance for a long time-if Chen were to lose the election-to make use of the instrument of a referendum in Taiwanese political practice.

Referendum results

The People of Taiwan demand that the Taiwan Strait issue be resolved through peaceful means. Should China refuse to withdraw the missiles it has targeted at Taiwan and to openly renounce the use of force against us, would you agree that the government should acquire more advanced anti-missile weapons to strengthen Taiwan's self-defense capabilities?

Would you agree that our government should engage in negotiations with China on the establishment of a "peace and stability" framework for cross-strait interaction in order to build consensus and ensure the welfare of the peoples on both sides?

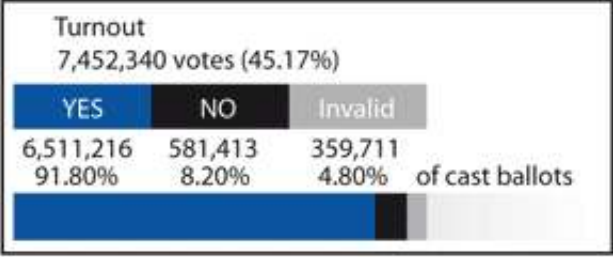

Turnout

$7,444,148$ votes $(45.12 \%)$

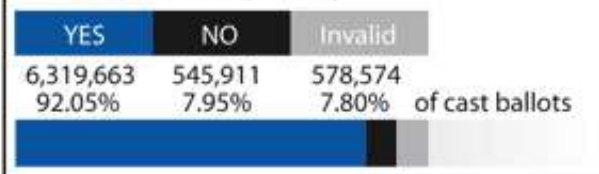

Source: Central Election Commission (CEC), Taiwan. threat, leading to a belief that it would be about Taiwan's independence, which would risk bringing about a conflict with China in which the United States would be forced to intervene. Byron Weng has clearly shown that this perception came from the idea, generally accepted in the United States, that a referendum called by the DPP would necessarily be on the independence of Taiwan, by reason of the former assimilation referendum=independence by the political programme of the pre-Chen Shui-bian DPP, but also because of Peking's conception of any referendum as quite literally a casus belli ${ }^{20}$. For the observers on the ground in Taiwan, this direct link was neither real nor credible, for one thing by reason of the opposition of a majority of the Taiwanese population to any provocative measure regarding China, and for another of the DPP's explicitly evolving position on this question. Ever since 1999, and the publication of its Resolution on the Future of Taiwan, the DPP has felt that declaring Taiwan independent by referendum serves no purpose, since Taiwan is the Republic of China and that it already constitutes a sovereign and independent country ${ }^{21}$.

It took the Chen administration over two months to calm the United States down and convince it that it would respect its previous commitment on the non-declaration of independence, thanks especially to the fine-tuning of the wording of the referendum 
questions all drawn up in collaboration with Washington, which made them decidedly more moderate (see Table 3). By mid-February, the United States, through Colin Powell, officially gave its consent to the referendum, thereby legitimising it again in part, at the same time letting its exasperation show through ${ }^{22}$.

Chen's recourse to Article 17 and the crisis with the United States allowed the blue camp to stigmatise the push by a president with authoritarian leanings, to contest the legality of using Article 17 in the absence of any war with China, and to present Chen as an irresponsible and dangerous politician for the people of Taiwan. This episode, and the atmosphere of political crisis fermented by the blue camp, were a serious set-back for Chen Shui-bian, as the polls quickly showed, by putting Lien and Soong in the lead ${ }^{23}$. Even if the legality of this recourse to Article 17 could not be easily contested, by virtue of the freedom of interpretation left to the President ${ }^{24}$, the Alliance's strategy of boycotting the referendum would be crowned with success, since only $45 \%$ of registered voters would take part in it, rendering it nul and void. Among the blue camp's leaders, only Wang Jin-pyng came out in favour of participating in the referendum ${ }^{25}$.

Contrary to a widely held view, it is not at all sure that the holding of the "defensive referendum" on March 20th really did Chen any good. Admittedly, Chen's firm stance with regard to Washington gave the impression of a President capable of standing up to the strongest pressures to defend the country's interests, or in any case those of the independence cause. The referendum also offered the DPP and the TSU a great opportunity to mobilise electoral arguments, allowing them to avoid a political debate around the government's performance-to the extent that in the last few months there was more discussion of the referenda than the election itself. Conversely, however, the "forced" side of the process, Washington's annoyance, and the Alliance's boycotting strategy gave a real boost to the blues' troops against Chen and what they considered to be irresponsible provocation of China ${ }^{26}$.

Other campaign themes

From November, the issue of the referendum acted as a phagocyte for the campaign. Other election themes and events had their importance, however; primarily the Constitution and the political reforms, the economic programmes and financial scandals, the personality of the candidates, and the large rallies that came at the end of the campaign.

41 On the constitutional questions and those of political reforms, we find the same situation for the referendum. Faced with Chen proposing the adoption by referendum of a new Constitution in 2006 and its implementation by 2008, the blue camp was first of all opposed to any idea of any constitutional revision other than simple amendments, and this in spite of the recognised inadequacy of the present Constitution to deal with the reality and needs of Taiwan. For the KMT, rewriting the Constitution would amount to opening Pandora's box. Yet, faced with the fact that a majority of the population supported the political reforms and the DPP plan for a new Constitution, the Alliance took a different tack by proposing an accelerated revision of the Constitution for 2005, yet without giving many details or guarantees ${ }^{27}$.

42 As to the political reforms that concerned in particular a reduction in the number of members of parliament, a change to the electoral system whereby voting would be for a single member, and the financing and economic assets of political parties, the Alliance, while promising to give its support to the reforms, managed to block the adopting of 
most of these laws. The law on political and election financing was passed three days after the ballot, preventing its application to this election. The blue camp, certain that it would win, preferred to put off the reforms to a later date in order to be in a better position to push through versions of them that would be more in their favour. Consequently, before the election, the blues projected an image of themselves as a conservative camp little inclined to promote reforms.

In terms of economic and social programmes, both camps put forward such similar proposals that it was difficult to see differences between them other than those that were cosmetic or electioneering. This was the case in particular of the programmes to stimulate the economy, on social cover and for the establishment of the "three direct links" with China (santong) for which almost the entire Taiwanese political class, with the exception of the TSU, was hoping for a rapid outcome by means of technical agreements bypassing the political issues. While Peking let it be understood that it was open to such technical solutions, its demand that its one-China principle be respectedsomething that Taiwan as a whole is against-, flies in the face of Taiwan's own demand for a "parity" of status in negotiations, and leaves little hope for any short-term solution. Thus, although the rapid introduction of the "three links" was one of Lien Chan's chief slogans and arguments for his election, it is hard to see how his victory could have speeded up the implementation of the "three links", other than by Peking favouring a party that shares its goal of an eventually united China. Chen's optimism about this is even more difficult to sustain.

On the theme of corruption and financial scandals, thanks to a constant media campaign orchestrated by the Alliance and its allies in the press and the audio-visual sector on allegations of embezzlement by President Chen and his entourage, the opponents of Chen Shui-bian and the DPP pulled off the feat of tarnishing their image of probity on which they have built their careers. The blue camp did not, however, come out of it cleansed of its corrupt image-Lien even joining Soong in the ranks of leaders having lost all credibility as to their personal probity and their opposition to "dirty money" (heijin). It succeeded, nonetheless, in transforming the theme of corruption, which had originally been very favourable to the DPP, into a zero sum game, at least for the duration of the campaign.

For its part, the theme of the personality of the candidates gave place to significant abuses by the blue camp which, in its character assassination of Chen Shui-bian, ended up publicly comparing him to Hitler, Saddam Hussein and Bin Laden. By refusing to apologise to Chen for these attacks ${ }^{28}$, and by taking up these themes in its post-election demonstrations and declarations, the Alliance and in particular Soong showed that these abuses were part of a deliberate tactic to assimilate Chen to a dangerous dictator, and were an attempt-one with real, albeit limited, success-to overturn classical images of the Taiwanese political discourse. Thus, the KMT and the PFP were purported to be the real democratic parties fighting for the people, and the DPP the dictatorial party. The success of this tactic rested on a particular conception of democracy dominant among pan-Blue supporters, in part linked to their feeling of having had power stolen from them by Chen Shui-bian in 2000. In their view, given that Chen was not legitimately, even if legally, President, and that he had a "majority" against him, he could "logically" only govern in a dictatorial and populist manner. This conviction was also fostered by the Alliance's campaign on the illegality of holding a referendum that was autocratically imposed to influence the election. Moreover, in spite of the fact that 
they enjoyed an absolute democracy, a great many blues supporters, mostly mainlanders, felt their very existence and survival on Taiwan to be threatened over the medium to long term by the pro-independence discourse, given their family background. Talking loudly about "green terror" (lüse kongbu) and oppression of the mainlander minority ${ }^{29}$, they were unable to grasp the democratic logic of giving power to the majority, and the impossibility for the DPP (even if it wanted to) to put them through what the Taiwanese majority endured through thirty years of KMT rule. Such feelings exist even among the most reasonable of people, and during the election campaign they were fed by the associations made by the DPP supporters between proTaiwan, pro-referendum democrats on the one side, and anti-referendum and antidemocrat, as well as lackeys of Communist China, on the other.

Finally, the campaign was marked by the first televised debates between the presidential candidates in the history of Taiwan and by two enormous election rallies. Neither of the debates had any particular influence on the electorate according to the polls, even if the media were in agreement in recognising that Chen made the better use of this tool of communication, although Lien Chan did make an improved showing in the second. As to the two big rallies, the first was organised on February 28th by the DPP and the TSU to commemorate the bloody events of February 28th 1947 and to celebrate Taiwanese identity and independence. Bringing together probably more than two million people who formed a human chain from the north to the south of the island, it gave the impression that victory was now a certainty for the green camp. The second took place on March 13th and was the response of the blue camp. It was called upon to show its strength and re-galvanise its troops demoralised by the success of the greens on February 28th, something that it achieved remarkably well by bringing together across the country crowds of a similar size or even slightly larger, calling for a change of president.

The situation on the eve of the ballot, the assassination attempt and Chen's re-election

As of March 10th, ten days prior to the election, all publication of opinion polls was banned. This prevented any assessment of the impact of the March 13th rally. The final official polls, however, were indicating an uncertain outcome, the difference between the two camps lying within a $3 \%$ margin of error ${ }^{30}$. During the days following March 13th, the blue camp announced publicly, however, that it had already won the election and that the final gap would amount to $8 \%$, maintaining the idea of a certain victory for its supporters. The green camp was much more circumspect and declared a narrow victory for Chen, the gap one way or the other to be, in its estimation, smaller than 120,000 votes, that is, less than $1 \%$ of the total ${ }^{31}$. The final week, marked by a noticeable increase in tension due to the uncertainty of the result, was punctuated by the twicedaily flurry of meetings of both camps which were to culminate in massive new rallies on the Friday night in Taipei. However, the attack on the President and Vice-President on March 19th prevented these final meetings from being held and, in the process, meant that the final mood of the electorate could not be gauged.

The following day, March 20th, Chen and Lu narrowly defeated the KMT-PFP alliance candidates. An analysis of the distribution of votes indicates that, with respect to the 2000 election, the green camp progressed in every region of the country except on the east coast, and was a clear winner overall in the southern and central circumscriptions and municipalities, at the same time as limiting the advance of the blues in the areas of Taipei and Taoyuan-Hsinchu. In all, the Chen-Lu ticket increased its vote by nearly 1.5 
million. As for the blue camp, it was swept away in the south and overtaken in the centre, but maintained its domination in the north. Its victory in the east carried little weight by virtue of the small number of voters. The results of the referendum, though with $90 \%$ support, could not be validated, on account of a lower than $50 \%$ turnout of registered voters.

The perpetrators of the assassination attempt on Chen and $\mathrm{Lu}$ and their motives are still unknown. The impact of this on the presidential election results is hard to assess. The attack was a shock for the whole population and left a deep impression on Chen's supporters. It left the blue camp incredulous and somewhat indifferent, until it became worried about a wave of sympathy capable of giving an advantage to Chen in the election the next day. By the end of the afternoon, rumours about a plot and a put-up assassination attempt began to spread before finally being expressed publicly on television by the ex-DPP pro-blue member of parliament, Chen Wen-chien (Sisy Chen), from the KMT's campaign headquarters. These rumours still abound today and are widely believed by the pan-blue voters in spite of their extravagant nature and the evidence to the contrary given both by the police and American experts assisting the enquiry ${ }^{32}$. Chen and Lu's very narrow victory margin and the polls showing both candidates running constantly neck and neck in the final weeks tends to credit the view that there was no significant wave of sympathy in Chen's favour.

The causes and consequences of Chen's victory

Chen's victory was above all else a victory of domestic and "national" politics. The electorate voted for a continuation and a broadening of institutional and constitutional reforms that would give a greater sense of Taiwanese national identity. It shows a rejection of the Alliance platform, which looked rather like a restoration of the KMT's power in its most orthodox version. The KMT and the PFP, buoyed by their advances in the polls during the greater part of 2003 and by the simple arithmetic of adding up the votes won by Lien and Soong in 2000 , believed that criticising Chen and presenting the case for a return to stability and a mix of catch-all measures and pronouncements would be enough to put them back in power. In actual fact, the blue camp lost more than $1,250,000$ votes with respect to its performance in 2000 . Its defeat was largely due to its inability to grasp the changes to the country over the past four years, which is moving increasingly away from the paternalistic and hierarchical social model of the 1980s, but also from the pan-Chinese ideology of the blue camp. The strong strides made by the green camp in the 2001 legislative elections should, however, have rung some alarm bells. The rivalry between Lien and Soong for the leadership of the Alliance and the subsequent power struggles feared by the population in case of their victory, also probably played against them.

51 Nonetheless, Lien and Soong almost won-a mere 30,000 votes making the difference-, so their campaign did convince nearly half the electorate. The reasons for this are first of all the force of Chen's rejection by a part of the population attached to an identification with China, and, the KMT image of being able to manage the economy, of having administrative experience and of stability that reassures the middle and upper classes. We must also bear in mind the attraction felt these classes and a section of the younger generation, especially among female voters, towards the new guard of KMT leaders, Ma Ying-jeou first and foremost, and the disillusionment with Chen felt by of a part of the electorate after 2000. This disillusionment led voters to abstain, or vote blue or cast an invalid vote, which explains the great number of such votes this time. The 
blue camp thus had managed to attract a certain number of former Chen voters who were disappointed with the performance of an inexperienced government.

Chen's success then can be explained on the one hand by the important transfer of votes that had gone to Lien Chan and Vincent Siew in 2000, at least in the order of $5 \%$ of voters, who chose to remain faithful to Lee Teng-hui rather than to a KMT moving away from the previous policy of Taiwanisation, or who were disgusted by the policy of systematic obstruction by the KMT and the PFP in Parliament. On the other hand, the attraction of Chen and his programme has been important for the younger generation born after 1975 which, Taiwanese born and bred or not, has to all intents and purposes known only an environment of democratisation and increasing social and moral freedom, and which identifies with Taiwan, not China, particularly in the south. Finally, we should not discard the idea that the population was quite simply satisfied with the government's performance ${ }^{33}$. The fact that the opposite impression seemed to prevail could be explained by the continual domination of the pro-Blue media and their constant criticisms of the government.

The Kuomintang and the blue camp therefore remain a major force in the Taiwanese political landscape. The KMT, even after possible new splits, will remain a pole of attraction for both the elites and voters at large. The undeniable charisma of Ma Yingjeou and other leaders of the second, even third generation of "mainlanders", as well as the mass of experts and people of quality gravitating around the KMT, guarantee it a future, in so far as it will be capable of really taking the Taiwanese-turn it had been reneging these past four years and of proposing real reforms that go in the direction wished for by the population. In this sense, the blue camp's defeat in 2004 is as much, if not more, a personal defeat for Lien and Soong and their passé line than it is of the KMT machine. If the KMT and the blue camp had put up other candidates, especially Wang Jin-pyng and Ma Ying-jeou, there is no doubt that they would have won, even if Chen improved on his 2000 score, which he probably would.

If not for a fusion with the KMT, the PFP is now likely condemned to the wilderness or a more or less radical opposition. As the party of a single man, Soong Chu-yu, and an ideology increasingly out of step with the population, it got all the votes it possibly could from those in favour of reunification, and knows that it will never be able to take power alone and based on this platform. Yet, it may still pose some problems for the KMT. After losing the presidency for the second consecutive time, the KMT is now in danger of losing votes in the legislative elections to be held in December 2004, by virtue of the die-hard attitude of Lien and Soong in their contesting of the results of the March 20th vote ${ }^{34}$. This attitude actually appeared to be more the refusal of a former ruling class to accept that its regime has come to an end to be replaced by a new elite, than the expression of concerns about democratic and administrative transparency. The KMT will therefore have no choice but to return to a position that is closer to that of the majority of Taiwanese, or else lose its pro-local wing and appear as a reactionary party, alongside the PFP ${ }^{35}$. Conversely, any oversharp turn by the KMT towards Taiwanisation would enable the PFP to get back those KMT voters with a marked panChinese ideology. A KMT led by a Ma-Wang tandem and based on internal reforms is thus a solution wished for by many. It would even allow hope of a return to a solution of a "united and democratic China". For that to happen, however, Lien and Soong would need to accept their defeat and retire, which is far from guaranteed. 
Finally, there is the possibility of a merging of the two, or even three, parties in the blue camp by including the NP. A sea snake of Taiwanese politics for three years, a possible merger would not settle any of the above-mentioned problems, however, even if it could give the opposition a semblance of unity and perhaps a soft landing for Lien, Soong and the present KMT leadership team. A great many ideological, tactical and factional snags could, however, prevent or limit the success and attraction of such a move, particularly among the electors, in the first place the mutual and ongoing mistrust between the KMT and the PFP, and the foreseeable clashes between "prolocal" supporters and the pan-Chinese plank of the "new" party.

After the Chen Shui-bian's victory and the turn-about of the KMT over the question of relations with China, the pro-independence option and the continuation of the separation with China under the lines of the present status quo have now been given full legitimacy. In the semantic debate raging between Peking, Washington and Taipei over this, the Taiwanese voters have chosen the line adopted by Chen and the DPP: the status quo means the independence and sovereignty of a Taiwanese state that is different from the Chinese one, with its own specific culture, history and political institutions, even if the majority of its population is of Chinese background.

These elections also showed a clear rise in the feeling of Taiwanese national identity which is likely to continue to grow in strength. This election was probably the last chance for the reunificationist or Chinese nationalist programme to assert itself through the ballot box. Peking, the KMT, the PFP and the NP have clearly understood this, which explains the violence of the blue camp's reactions, unable as it was to accept, not the election defeat as such, but the end of their view of the world, in other words the end of their state as a country that was Chinese first and Taiwanese second. On the other hand, this does not seem to be yet well grasped in Washington, either on the Republican or Democrat side, probably because it brings into question the basis of the bi-partisan policy of the United States towards Taiwan that has been in place for thirty years. The idea of a reunification with China is not totally eliminated, but it would now necessarily require either coercion, or the democratisation of China. But coercion or military conquest would have huge international repercussions, and would probably also mean the occupation of a country and repression by what would be perceived as a foreign power by a Taiwanese population that is already more than $95 \%$ opposed to the "pacific" "one country, two systems" model of reunification ${ }^{36}$. The other possible path is through the democratisation of China, authorising the creation of federal or confederate constitutional structures or structures along the lines of the European Union, ratified by the Taiwanese people in a referendum.

Another characteristic of this election campaign was the generalisation of Taiwanese as a language in political speeches and discussions by all the political parties, including the PFP. On television, in Parliament and at election meetings, Taiwanese was constantly being used in competition with Mandarin, even to the point of being virtually the sole language used in the south and in some speeches by "Taiwanese bornand-bred" leaders. This feature, which can only become more marked, is moreover one of the factors feeding the insecurity and anxiety of those members whose families come from the mainland, but also of those Hakka families from the north of the island, who have not learned Taiwanese or who speak it badly, and who feel increasingly marginalised by the changes in society, even in Taipei ${ }^{37}$. 
Finally, there seems to have been a general consensus favouring the setting up of the "three direct links" with China and the continuation of Taiwanese economic investments in China. This attitude, which appears to be in contradiction with the affirmation of Taiwanese identity, is the expression first and foremost of a pragmatic concern to improve the competitiveness and the economic situation of the island, while commercial exchanges with China, which have made a spectacular leap forward, have become a major factor in this. It also expresses the ability to make a clear distinction between economic co-operation and political and cultural identity. The Chinese strategy of appealing to the Taiwanese through the economic boom on the mainland has failed. The activities of the Taiwanese in China have even, for some, strengthened the feeling of a radical difference in "national" type between the two shores of the Strait, in spite of their common cultural origins.

With the election of Chen Shui-bian as President of the state of Taiwan, we may therefore wonder whether we have witnessed the penultimate step in the formation of a new Taiwanese nation, with Chen as the "new father of the nation" to be born (xin guojia zhi fu) ${ }^{38}$. In any case, now that he has been re-elected, Chen will have as his main goal the rewriting of the Constitution and its implementation by 2008, while respecting his repeated commitment to Washington and Peking not to tamper with the official name, symbols or territory of the Republic of China. For Chen, the fact that Taiwan is called the Republic of China, pending the democratisation of the People's Republic, is one acceptable compromise, about which the majority of Taiwanese seem also to be in agreement.

\section{NOTES}

1. Cf. Charles Snyder, "Siew: Recount bid futile", Taipei Times, April 8th 2004.

2. Cf. Philip P. Pan, "Election in Taiwan is a vote on China", Washington Post, March 19th 2004.

3. The Taiwanese presidential election has only a single round, the President being elected by a plurality of the votes. In 2000, Chen, taking advantage of the scattering of votes in the blue camp, was elected with only $40 \%$ of the total vote.

4. On the 2000 elections, see Joseph Wu Jausieh, "After the watershed, the uncertainties", China Perspectives, No. 29, May-June 2000, pp. 25-35.

5. Cf. Hsieh Chun-man and Shang Tao-ming, "Defeated New Party Brass take flight across the Strait", Win-Win Weekly (Jin zhoukan), November 4th 2002, reprinted in the Taipei Times, November 23rd 2002.

6. This was particularly the case with Lai Shyh-bao, an NP member of Parliament defeated in 2001 and now head of the Taipei Council for Economic Development. Cf. Huang Chuang-hsia, "Lai Shibao bang Ma Yingjiu 'qiu' hui le shimao er guan (Lai Shyhbao helps Ma Ying-jeou to recover the second building of the International Congress Centre)", Business Weekly (Shangye zhoukan), No. 797, March 3rd 2003. Ma was the KMT leader who most strenuously supported the NP's inclusion in the Alliance for the presidential campaign. Cf. Lin Ying-hsiu, "Lian Zhan qibao/ Ma Yingjiu ti'an bu paichu 
Xindang (Lien Chan gets going/ Ma Ying-jeou proposes not to sideline the New Party)", ETT News on-line (Dongsen xinwen), March 1st 2003.

7. Source: The Central Electoral Commission. The minimum legal voting age in Taiwan is 20 .

8. From the time of the presidential campaign in 2000, Lien Chan set himself apart from Lee by projecting the image of a moderate on the question of relations with China. His "Ten Articles" propose a return, with even greater flexibility, to the Guidelines for National Unification laid out by the KMT government in 1991 and set aside during the latter years of the Lee Teng-hui era. They include the Taipei agreement for the opening of political dialogue with Peking on unification, on the sole basis of Peking's goodwill. Cf. Yu-shan Wu, "Taiwan's domestic politics and cross-Strait relations", Conference at the Universities Service Center, Hong Kong, January 6th-7th 2004, http:// www.ipsas.sinica.edu.tw/image/ipsas/1/20.doc

9. Lien Chan invited Chiang Ching-kuo's former Prime Minister, Sun Yu-chüan, bedridden and in a wheel-chair, to address the great rally of March 13th 2004, in order to have him painfully proclaim his support for the Alliance.

10. Cf. Yu-shan Wu, op. cit. On the attraction of Shanghai, see Frédéric Bobin, "La 'fièvre de Shanghai' fait tourner la tête à 300000 Taiwanais" [Shanghai fever makes 300,000 Taiwanese swoon], Le Monde, December 3rd 2001.

11. The Journalist (Xin xinwen) puts this fortune at something between NT\$1.3 billion (figure given by the KMT in 2004) and NT $\$ 20$ billion (US $\$ 1=\mathrm{NT} \$ 34$ ). According to Lien Chan's own friends, quoted in an official promotional book published for the 2000 campaign, it could be in the order of NT\$5 to NT\$6 billion. Cf. Chin Heng-wei (editor-inchief of the journal Dangdai), "What Lien's pals think his assets are worth", Taipei Times, January 9 th 2004.

12. On the particular role of Therese Shaheen, head of the American Institute in Taiwan, in the planning of this trip and its consequences for relations between Taiwan and the United States, see Susan V. Lawrence, "The guardian angel finally had enough", Far Eastern Economic Review, April 22nd 2004.

13. Cf. Ching Cheong, "Chen puts presidential rivals on defensive", Straits Times, December 27th 2003. See also Byron Weng, "The status quo in the Taiwan Straits has changed", Taiwan Perspective e-paper, No. 15, March 30th 2004.

14. Cf. Chang Yun-ping, "Pan-blue allure fading, poll shows", Taipei Times, December 9th 2003, and Frank Ching, "Ball now in China's court on Taiwan independence", Japan Times, December 24th 2003.

Already on October 18th, the Lianhe bao (United Daily News) published a poll indicating an increase of $6 \%$ over a year in the number of people identifying as Taiwanese, totalling $62 \%$, as against $19 \%$ identifying as Chinese (without offering the dual category of Chinese-Taiwanese).

15. For example, Lien Chan's immediately burying the suggestion made in November 2003 by Hung Yu-chin, a member of the KMT's permanent central committee and a historical figure in the pro-local current, to rebaptise the KMT or Chinese Nationalist Party as the Taiwanese Nationalist Party. But the debate may well resurface, as Hung reiterated his proposal three weeks after the election, cf. Huang Tai-lin, “Top KMT figure plays name game", Taipei Times, April 8th 2004.

16. Born in 1936 and educated in China after the departure of his family from Taiwan, Lien Chan did not come to Taiwan until after Chiang Kai-shek took control of the island in 1945 and his father Lien Chen-tung returned with the KMT. According to Ku Er-teh, who cites an academic study by Lin Yuan-huei published in Taiwan: A Radical Quarterly in 
Social Studies, the departure from Taiwan of his father and his grand-father Lien Heng was apparently due to an overly conspicuous collaboration with the Japanese colonial regime and its subsequent rejection of the Taiwanese community, cf. Ku Er-teh, "The book that built the Lien family", Taipei Times, February 6th 2004.

17. On December 15th Wang Jin-pyng announced the KMT's official rejection of the "1992 Consensus" and refused to eliminate independence as a possible option for the island in the future. The following day Lien Chan confirmed this rejection and the overall political reorientation of the KMT. Cf. "Lien shifts stance towards independence", China Post, December 17th 2003. On the "1992 Consensus", see Su Chi, "The Significance and Contribution of the 'One China, Different Interpretations' Consensus", Taiwan Security Research, http://taiwansecurity.org/TS/2002/SU-1202.htm, December 20th 2002.

18. Moreover, Peking was not mistaken in this when it supported the pan-blue forces to the extent of allowing the blue camp to organise election meetings with Taiwan businessmen resident in China. Cf. "Taiwan businessmen join political lobby", Associated Press, February 5th 2004.

19. Cf. David Stout, "Bush tells China leader he opposes Taiwan's referendum”, New York Times, December 9th 2003.

20. Byron Weng, op. cit.

21. See the brochure outlining the general programme of the Democratic Progressive Party (DPP) Critical time: Striding towards reform, DPP Party Headquarters, November 2002.

22. The battle that took place in the United States and even within the Bush administration on the question of the Taiwanese referenda was one of the important factors in the final decision. It would require a separate analysis taking account of the overall Chinese policy of the United States. For articles explicitly defending the US's global interest in the region and trying to keep a certain balance between Taipei and Peking, but rather more understanding towards China's position, see for instance Michael D. Swayne, “Trouble in Taiwan”, Foreign Affairs, March-April 2004, and Ralph Cossa, “Does Taiwan's leader know when to stop?”, International Herald Tribune, December 17th 2003. For a clearly pro-Taiwan position, see the articles by members of the ultra-conservative think tank, the Heritage Foundation, like John Takcik and Harvey Feldman, or the declarations by members of the Taiwan Caucus in the American Congress who strenuously criticised the "reprimand" given by Bush to the Chen government.

23. However, as early as December 30th, a China Times poll gave the lead back to Chen by $2 \%$ over Lien.

24. The view taken by Taiwanese legal experts on the question generally comes out in favour of the legality of Chen's decision. In actual fact, it involves much more a question of legitimacy than of legality, as Chen, a lawyer by profession, must have known.

25. However, as noted by Gary Rawnsley, 58 \% of those voting in the presidential election also voted in the referendum. Cf. G. Rawnsley, "The Day after the Night Before", Taiwan Perspective e-paper, No. 19, April 12th 2004.

26. For an analysis along these lines, see David W. F. Huang, "A potential impact of the referendum on voting decisions in the Taiwanese presidential election", Taiwan Perspective e-paper, nํ 5, 23 February 2004. 
27. Cf. “Taiwan's Opposition Embraces New Constitution Plan”, Reuters, November 17th 2003.

28. Cf. "KMT apologizes about Hitler ad-but not to Chen", Taipei Times, March 13th 2004.

29. In reference to the former "white terror" (baise kongbu) that the KMT, under the leadership of Chiang Kai-shek and his son imposed for more than ten years after the events of February 28th 1947.

30. Cf. Report and Commentary: Taiwan 2004 Presidential Election and Aftermath, Taiwan Foundation for Democracy, March 24th 2004, 11 pp.

31. Press conference by Chiou I-jen, DPP campaign head, to the international press, March 16th 2004.

32. Cf. BBC News Online, “Taiwan Election 'Conspiracy”, March 30th 2004, and AFP, "Shooting of Taiwan's Chen 'Not Self-Inflicted': US Forensic Expert”, April 11th 2004.

33. For such an interpretation, see especially G. Rawnsley, op. cit.

34. Cf. Lawrence Chung, "Why Lien is losing out", Straits Times, April 14th 2004, or Kirby Chien, “Taiwan Opposition Leader Faces Calls for Reform”, Reuters, April 12th 2004.

35. The temptations of insurrectional violence of the reactionary revolutionary type are visible and can be clearly heard among the PFP's leaders and supporters, Soong first and foremost, but not much in the KMT, except perhaps Lien Chan himself, who seems incapable of imagining any other future than as state President. The PFP was in fact the main organisor of the repeated protests and violent clashes with police since March 20th, aimed at contesting the election of Chen and Lu. Its leaders called for the overthrow of the government, a revolution for justice and breaking into the presidential palace. See the reports of the clashes between PFP members and the opposition "tough guys"with the Taipei police on the nights of March 20th, 26th and 27th and April 3rd and 10th.

36. For a deliberately alarmist discussion of the possible success of a lightning invasion of Taiwan by Peking as early as 2006, see the analysis by Wendell Minnick, Jane's Defence Weekly's correspondent on Taiwan “The year to fear for Taiwan: 2006”, Asia Times, April 10th 2004. On the balance of forces and a general outline of possible conflict between China and Taiwan, see Jean-Pierre Cabestan, Chine-Taiwan: la guerre est-elle concevable? [China-Taiwan. Is War Conceivable?], Paris, Economica, 2003.

37. See, for instance, Kathrin Hille, "Soul-searching in Taiwan as poll splits opinion", Financial Times, March 23rd 2004.

38. Cf. Kao Tien-sheng, "Taiwan zhi zi jiang cheng xin guojia zhi fu" (Taiwan's son on the way to becoming the new father of the nation) Xin Taiwan (New Taiwan), No. 406, January 3rd-9th 2004, pp. 14-18. 